\title{
CONSTITUTIONAL LAW
}

\section{JOURNAL OF}
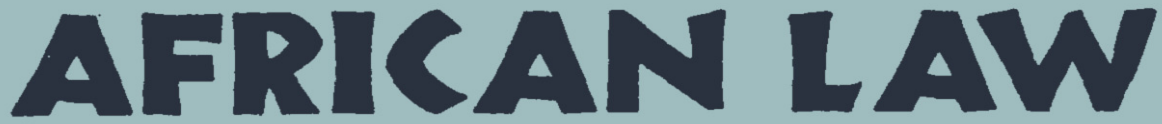

Official organ of the

INTERNATIONAL AFRICAN LAW ASSOCIATION

[1964] J.A.L.

Autumn 1964

Vol. 8, No. 3

Edited by A. N. ALLOTT

CONTENTS

NOTES AND NEWS

153

INTERNATIONAL AFRICAN LAW ASSOCIATION NEWS

AFRICAN PRESIDENTIALISM: A COMPARISON OF THE "EXECUTIVE" UNDER THE CONSTITUTIONS OF THE FEDERATION OF NIGERIA, THE FEDERAL REPUBLICS OF THE CONGO AND CAMEROON, AND THE REPUBLICS OF GHANA, CHAD, CONGO, AND THE ENTENTE

J. C. Juergensmeyer

LEGISLATION

The Constitution of Malawi, 1964

Simon Roberts

178

\section{CASES}

Digest of decisions on the Nigerian constitution

Sir Lionel Brett

\section{CORRESPONDENCE}

The Ombudsman and one-party states in Africa REVIEWS

\section{LONDON \\ BUTTERWORTHS}




\section{EDITORIAL COMMITTEE}

A. N. Allott, Professor of African Law, University of London (Managing Editor).

J. N. D. Anderson, O.B.E., LL.D., Professor of Oriental Laws, University of London.

H. F. Morris, School of Oriental and African Studies, University of London (Assistant Editor).

A. Phillips, O.B.E., J.P., Professor of English Law, University of Southampton.

J. S. Read, Faculty of Law, University College, Dar es Salaam.

I. Schapera, D.Sc., Professor of Anthropology, University of London.

\section{NOTES TO CONTRIBUTORS}

1. Manuscripts should be typed in double spacing on one side of the page only.

2. They should be sent to:-Professor A. N. Allott, Department of Law, School of Oriental and African Studies, University of London, 38, King St., London, W.C.2.

3. It is regretted that no payment can at present be made to contributors; but authors of articles receive 25 offprints free of charge.

4. Business communications (e.g., in regard to subscriptions or advertisements) should be sent to:-Messrs. Butterworth \& Co. (Publishers) Ltd., 88 Kingsway, London, W.C.2, and not to the Editor.

\section{THE}

\section{INTERNATIONAL AFRIGAN LAW ASSOGIATION}

The Association is concerned with all aspects of the laws of African countries. Membership of the Association, which is in two classes, individual and corporate, is open to all those with a professional interest in African Law. The current rates of subscription (entitling members to receive the official organ of the Association, the Journal of African Law, free of charge) are:Individual member: $£ 2.12 .6$ (or $\$ 7.50$ ) per annum.

Corporate member: $£ 5.5 .0$ (or $\$ 14)$ per annum.

The official languages of the Association are English and French.

For further information on the organization and activities of the Association, write to the Secretaries-General-Professor A. N. Allott, School of Oriental and African Studies, University of London, 38, King St., London, W.C.2, England; or Professor M. Alliot, 23, Quai de Boulogne, Boulogne-Súr-Seine, Seine, France.

Three issues a year

Annual Subscription . . . 42s., including postage

Single copies . . . 15s. each 